\title{
A Novel Assay Method for Aminopeptidase P and Partial Purification of Two Types of the Enzyme in Escherichia coli ${ }^{\dagger}$
}

\author{
Tadashi Yoshimoto, Nobuhiro Murayama and Daisuke Tsuru \\ School of Pharmaceutical Sciences, Nagasaki University, \\ Nagasaki 852, Japan \\ Received January 25, 1988
}

\begin{abstract}
A new assay for aminopeptidase $\mathrm{P}$ was established by coupling with proline iminopeptidase using Gly-Pro-chromogen (e.g. Gly-Pro- $\beta$-naphthylamide, Gly-Pro-p-nitroanilide, or .Gly-Pro-4methyl coumarin amide) as the substrate. With each substrate, a linear relationship was established between the enzyme amounts and color development or fluorescence due to the chromogen released. This assay method did not suffer from interference by materials in culture broth. By using this assay method, aminopeptidase $\mathrm{P}$ was partially purified from Escherichia coli HB101 by chromatographies on DEAE-Sephadex and high performance liquid chromatography (HPLC). On the chromatogram with a DEAE-Sephadex column, two peaks of aminopeptidase $P$ were observed and were named APP-I and APP-II. APP-I was further purified by HPLC using DEAE-5PW and Phenyl-5PW columns. Optimum pHs of APP-I and APP-II were 8.0 and 9.0, respectively. In contrast to APP-I which was stable around $\mathrm{pH} 10$, APP-II was stable at $\mathrm{pH} 8$ to 9 . After incubation for $30 \mathrm{~min}$ at $\mathrm{pH} 8.0$, fifty percent of the remaining activity of APP-I and APP-II were observed at

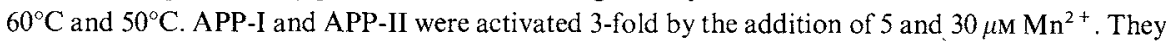
were inhibited by EDTA, and reactivated by adding $\mathrm{Mn}^{2+}$. The molecular weights of APP-I and APP-II were 350,000 and 210,000 , respectively. Each enzymes released the amino terminal amino acid when proline is at the penultimate position. The velocity of hydrolysis by the enzymes was not significantly different for most $\mathrm{X}$-Pro bonds ( $\mathrm{X}=$ amino acid) of peptides except for Pro-Pro bond. APP-II hydrolyzed penta-(Pro-Pro-Gly) at a much higher rate than APP-I, suggesting the aminopeptidase $\mathbf{P}$ reported by Yaron and Mlynar $(B B R C, 32,658(1968))$ to be APP-II.
\end{abstract}

Aminopeptidase P (EC 3.4.11.9) is a peptidase which hydrolyzes the amino acidproline bond when proline is in the penultimate position from the amino terminal. The enzyme has been found in Escherichia coll, ${ }^{1}{ }^{1}$ Neisseria gonorrhoease ${ }^{2)}$ and pig kidney. ${ }^{3,4)}$ Yaron et al. ${ }^{1)}$ and Dehm and Nordwig' ${ }^{3)}$ assayed the enzyme activity by the ninhydrin method using poly-proline and Gly-Pro-Hyp as substrates, respectively. Chen and Buchanan $^{23}$ detected enzyme activity by high voltage electrophoresis. Color development by ninhydrin reaction is sometimes very troublesome, especially when enzyme preparations are crude, and high voltage electrophoresis is not fit for a routine assay method of the enzyme activity. Due to these reasons, the enzymatic characteristics and protein structure have remained unclear.

We have previously reported that aminopeptidase $\mathrm{N}$ in $E$. coll $^{5}$ ) has not only arylamidase activity but also peptidase activity which is supposedly concerned with peptide catabolism in E. coli. However, this enzyme

† This study was supported in part by the Research Fund of the Nagasaki Super Technology Development Association.

Abbreviations: MCA, 4-methyl-coumaryl-7-amide; 2-NNap, $\gamma$-naphthylamides; pNA, $p$-nitroanilide; PCMB, $p$ chloromercuribenzoate; PMSF, phenylmethane sulfonylfuoride; DFP, diisopropylphosphoro fluoridate; EDTA, ethylenediaminetetra acetate; Hyp, hydroxyproline.

All optically active amino acids are L-configuration. 
cannot hydrolyze amino acid-proline bonds and, therefore, cooperation of aminopeptidase $\mathrm{P}$ and proline iminopeptidase seems necessary for complete hydrolysis of proline-containing peptides. From this point of view, aminopeptidase $\mathbf{P}$ seemed to be important for processing amino terminal amino acids.

This paper describes the enzyme assay method and partial purification of aminopeptidase $\mathrm{P}$ from $E$. coli, adopting this method to assay the activity.

\section{MATERIALS AND METHODS}

Materials. $p$-Chloromercuribenzoate (PCMB) and proline iminopeptidase from Bacillus coagulans ${ }^{6}$ ) were purchased from Nakarai Chemicals. Bovine pancreas trypsin and Fast Garnet GBC salt were from the Sigma Chemical Co. Gly-Pro- $\beta$-naphthylamide (Gly-Pro-2-NNap) was obtained from Novabiochem. Gly-Pro-4-methyl-coumaryl-7amide (Gly-Pro-MCA), Gly-Pro-p-nitroanilide (Gly-PropNA), bestatin, amastatin, and peptides were from the Protein Research Foundation, Minoh. Horse heart muscle catalase, bovine pancreas chymotrypsinogen, and rabbit. heart muscle aldolase were obtained from BoehringerMannheim. Ala-Pro-pNA, Glu-Pro-pNA, His-Pro-pNA, Lys-Pro-pNA, and Ser-Pro-pNA were kindly supplied by Dr. A. Barth, Martin-Luther University. Dipeptidyl aminopeptidase IV from lamb kidney ${ }^{7)}$ and proline-specific endopeptidase from Flavobacterium meningosepticum ${ }^{8\}}$ were the same samples used previously. Hydroxyapatite was prepared by the method of Bernardi. ${ }^{9 !}$

\section{Assays of aminopeptidase P Activity.}

(A) Gly-Pro-2-NNap substrate. To $700 \mu \mathrm{l}$ of $20 \mathrm{~mm}$ Tris- $\mathrm{HCl}$ buffer, $\mathrm{pH} 8.0$, were added $100 \mu \mathrm{l}$ of $2 \mathrm{~mm}$ GlyPro-2-NNap dissolved in the same buffer and $100 \mu$ of enzyme sample. After $15 \mathrm{~min}$ of incubation at $37^{\circ} \mathrm{C}$, enzyme reaction was stopped by heating in boiling water for $2 \mathrm{~min}$. Proline iminopeptidase $(0.3$ unit) in $100 \mu \mathrm{l}$ of $20 \mathrm{~mm}$ Tris-HCl buffer, $\mathrm{pH} 6.8$, was added to the solution. After $30 \mathrm{~min}, 500 \mu \mathrm{l}$ of Fast Garnet GBC solution $(1 \mathrm{mg} / \mathrm{ml})$ containing $10 \%$ Triton $\mathrm{X}-100$ in $1 \mathrm{M}$ acetate buffer ( $\mathrm{pH} 4.0$ ) was added, and the reaction mixture was left for $25 \mathrm{~min}$ at $37^{\circ} \mathrm{C}$. The absorbance was measured at $550 \mathrm{~nm}$. One unit of the enzyme activity was defined as the amount of the enzyme that released $1 \mu \mathrm{mol}$ of $\beta$-naphthylamine per min under the standard conditions.

(B) Gly-Pro-pNA substrate. The reaction mixture was composed of $0.2 \mathrm{~mm}$ Gly-Pro-pNA and test enzyme in $1 \mathrm{ml}$ of $20 \mathrm{~mm}$ Tris- $\mathrm{HCl}$ buffer, $\mathrm{pH} 8.0$. After $15 \mathrm{~min}$ of incubation at $37^{\circ} \mathrm{C}$, the enzyme reaction was stopped by adding $1 \mathrm{ml}$ of $20 \mathrm{~mm}$ EDTA in $200 \mathrm{~mm}$ Tris $\mathrm{HCl}$ buffer, pH 6.8 , then $1 \mathrm{ml}$ of proline iminopeptidase ( 0.4 unit) was added. After incubation at $37^{\circ} \mathrm{C}$ for $30 \mathrm{~min}$, absorbance was measured at $410 \mathrm{~nm}$.

(C) Gly-Pro-MCA substrate.: To $700 \mu \mathrm{l}$ of $20 \mathrm{~mm}$ Tris$\mathrm{HCl}$ buffer, $\mathrm{pH} 8.0$, were added $100 \mu \mathrm{l}$ of $2 \mathrm{~mm}$ Gly-ProMCA dissolved in the same buffer and $100 \mu \mathrm{l}$ of enzyme sample. The enzyme reaction was stopped by adding $1 \mathrm{ml}$ of $20 \mathrm{~mm}$ EDTA in $200 \mathrm{~mm}$ Tris- $\mathrm{HCl}, \mathrm{pH} 6.8$. After adding $100 \mu$ l of proline iminopeptidase ( 0.5 units), the solution was incubated at $37^{\circ} \mathrm{C}$ for $30 \mathrm{~min}$, the fluorescence of 7-amino-4-methylcoumarin released being monitored using a spectrofluorometer with excitation at $370 \mathrm{~nm}$ and emission at $440 \mathrm{~nm}$.

Cultivation of E. coli HB101. E. coli was cultivated in a bouillon medium containing $1 \%$ Polypepton, $1 \%$ meat extract, and $0.5 \% \mathrm{NaCl}, \mathrm{pH} 7.0$, at $37^{\circ} \mathrm{C}$ for $20 \mathrm{hr}$ using a Micro Fermentor, New Brunswick Co. Cells were harvested by centrifugation at $8,000 \mathrm{rpm}$ for $15 \mathrm{~min}$, washed with cold $50 \mathrm{~mm}$ borate-Na buffer, $\mathrm{pH} 9.0$, and were used for the enzyme purification.

Purification of Aminopeptidase $P$. All the purification procedures were done at $4^{\circ} \mathrm{C}$. The washed cells $(40 \mathrm{~g}$ wet weight) were suspended in $200 \mathrm{ml}$ of $20 \mathrm{~mm}$ borate- $\mathrm{Na}$ buffer, $\mathrm{pH} 9.0$, and disrupted for $10 \mathrm{~min}$ with glass beads in a Dyno-Mill. The glass beads were removed by decantation and the disrupted cell suspension was centrifuged to remove intact cells. The intact cells were again treated as above, and the supernatants were combined. After centrifugation at $8,000 \mathrm{rpm}$ for $15 \mathrm{~min}$, the supernatant was fractionated by ammonium sulfate at 40 to $80 \%$ saturation. The precipitate was dissolved in a small volume of $20 \mathrm{~mm}$ borate- $\mathrm{Na}$ buffer, $\mathrm{pH} 9.0$, and desalted by gel filtration on a Sephadex G-25 column, and the enzyme fraction was put on a column $(2.5 \times 30 \mathrm{~cm})$ of DEAE-Sephadex equilibrated with the same buffer. The adsorbed enzyme was eluted with an increasing linear gradient of $\mathrm{NaCl}$ concentration to $0.7 \mathrm{M}$. Two peaks (APPI and APP-II) of active fractions were separately combined and the enzymes were precipitated by $80 \%$ saturation of ammonium sulfate. Each enzyme, APP-I and APP-II, was

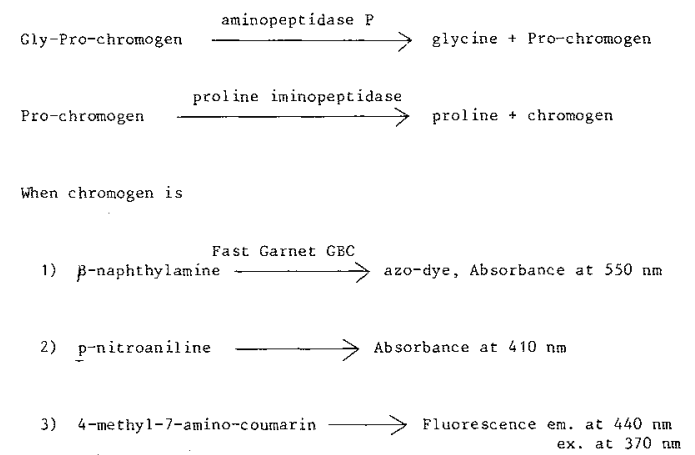

FIG. 1. Activity Assay Method for Aminopeptidase P Using Gly-Pro-Chromogens as Substrate. 
repeatedly chromatographed on DEAE-Sephadex. APP-I was further purified by HPLC after being desalted by Sephadex G-25 $(1 \times 40 \mathrm{~cm})$ and concentrated by Amicon ultrafiltration: the enzyme fraction was chromatographed by HPLC using a DEAE- 5 PW column $(7.5 \times 75 \mathrm{~mm})$ with a linear gradient system of $\mathrm{NaCl}$ in $20 \mathrm{~mm}$ Tris- $\mathrm{HCl}$ buffer, pH 7.8, and hydrophobic chromatography on a Phenyl-5PW column $(7.5 \times 75 \mathrm{~mm})$ equilibrated with the same buffer. The active fractions were combined and kept at $4^{\circ} \mathrm{C}$ until use.

Substrate specificity. Hydrolyses of amino acid-Pro-2NNap and amino acid-Pro-pNA were assayed by the standard assay method. Hydrolyzing sites of peptides and the above substrates were analyzed by TLC using $n$ $\mathrm{BuOH}-\mathrm{AcOH}-\mathrm{H}_{2} \mathrm{O}(4: 1: 2)$ as a solvent and comparing with authentic markers. The products were visualized by spraying with ninhydrin solution.

Estimation of molecular weight. Molecular weight was estimated by gel filtration using HPLC with a TSK G$3000 \mathrm{SW}$ column. Thyroglobulin $(669,000)$, apoferritin $(443,000), \beta$-amylase $(200,000)$ and alcohol dehydrogenase $(150,000)$ were used as protein markers.

\section{RESULTS}

\section{Assay of aminopeptidase $P$}

The principle of the enzyme activity assay is shown in Fig. 1. The products released by the action of aminopeptidase $\mathrm{P}$ were further hydrolyzed by proline iminopeptidase and the chromogenic substances liberated ( $\beta$-naphthylamine, $p$-nitroaniline, and 4-methyl-7coumarin) were followed spectrophotometrically. Figure 2 shows the concentration of proline iminopeptidase necessary for complete liberation of $\beta$-naphthylamine from Pro-2NNap, the enzymatic product by the action of aminopeptidase P. One-third of a unit of proline iminopeptidase was found to be enough for assays of aminopeptidase $P$ with three different substrates, Gly-Pro-2-NNap, GlyPro-pNA, and Gly-Pro-MCA.

Figure 3 shows the relationship between the amounts of aminopeptidase and $\beta$-naphthylamine liberated, indicating the linear relationship between them. The same good linearity was observed between enzyme concentrations and products released for the proline iminopeptidase-coupled methods with the other two chromogenic substrates. These methods

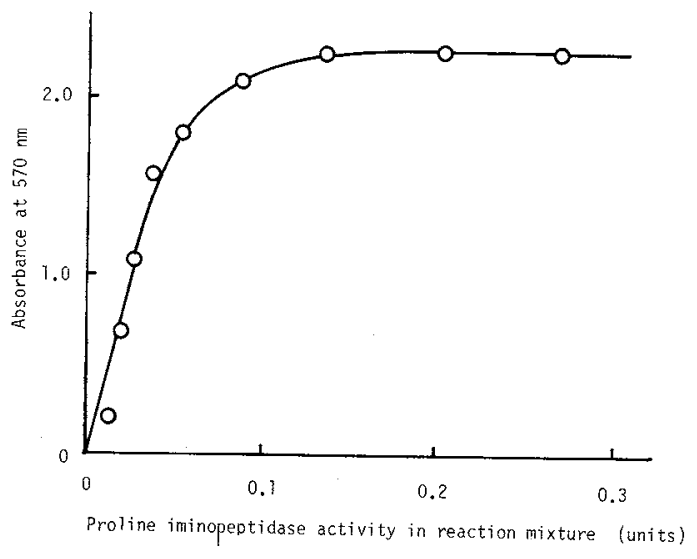

FIG. 2. Effects of the Concentration of Proline Iminopeptidase on Assay of Aminopeptidase P.

Enzyme activity was assayed by the standard assay method except for proline iminopeptidase activity.

made it possible to measure enzyme activity even when the enzyme preparations were crude. The enzyme activity of kidney extract that shows high dipeptidyl aminopeptidase IV activity was also measurable in the presence of DFP by these methods (data not shown).

\section{Purification of aminopeptidase $P$}

The purification procedure for aminopeptidase $\mathbf{P}$ is summarized in Table I. The enzyme was eluted at 0.25 and $0.4 \mathrm{M} \mathrm{NaCl}$ from a DEAE-Sephadex column (Fig. 4), the enzyme peaks were named APP-I and APP-II, respectively, and APP-I was further purified by HPLC. However, both enzyme preparations were still heterogenous: they were contaminated with three minor impurities, as seen by disc gel electrophoresis.

\section{Enzymatic and physicochemical properties of two aminopeptidase $P$}

The optimum pHs of APP-I and APP-II were 8.0 and 9.0, respectively. APP-I was stable around $\mathrm{pH} 10$ and APP-II was stable at $\mathrm{pH} 8$ to 9 . After $30 \mathrm{~min}$ at $\mathrm{pH} 8.0$, fifty percent of the remaining activities of APP-I and APPII were observed at $60^{\circ} \mathrm{C}$ and $50^{\circ} \mathrm{C}$ (Table II). The molecular weights of APP-I and APP-II estimated by gel filtration were 350,000 and 210,000, respectively (Fig. 5). 


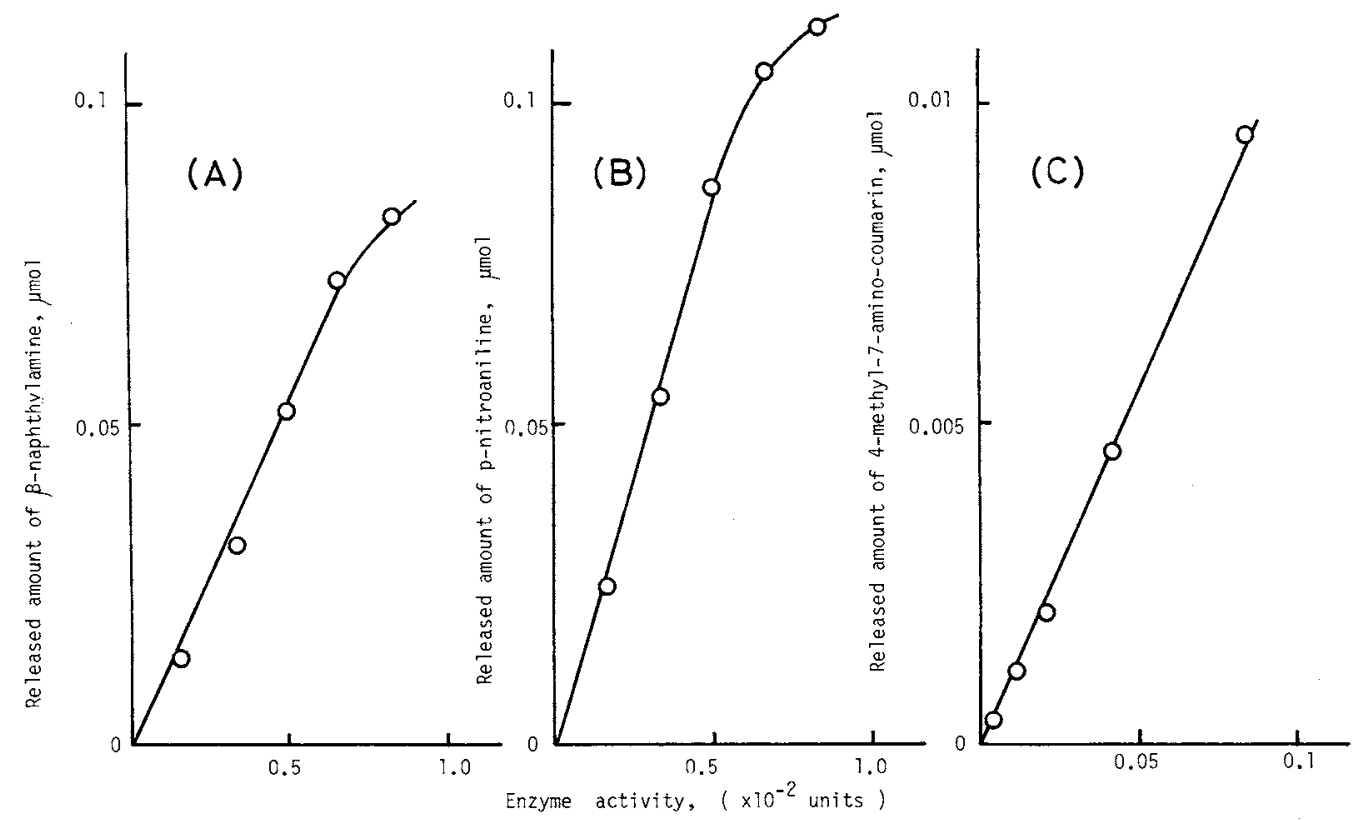

FIG. 3. Relationship between Enzyme Amount and Product Liberation by the Standard Assay Methods Using Gly-Pro-2-NNap (A), Gly-Pro-pNA (B), and Gly-Pro-MCA (C) as Substrates.

See MATERIALS AND METHODS for the experimental procedures.

Table I. Purification of Aminopeptidase P from $E$. coli HBi0l

\begin{tabular}{lccccc}
\hline \multicolumn{1}{c}{ Purification } & & $\begin{array}{c}\text { Total activity } \\
\text { (unit) }\end{array}$ & $\begin{array}{c}\text { Specific activity } \\
\text { (unit/mg) }\end{array}$ & $\begin{array}{c}\text { Recovery } \\
\text { (\%) }\end{array}$ & $\begin{array}{c}\text { Purification } \\
\text { (fold) }\end{array}$ \\
\hline \multirow{2}{*}{$\begin{array}{l}\text { Cell-free extract } \\
\text { Ammonium sulfate fractionation }\end{array}$} & 106 & 0.005 & 100 & 1 \\
DEAE-Sephadex & APP-I & 95 & 0.0056 & 90 & 1.1 \\
& APP-II & 23.1 & 0.036 & 35 & 7.1 \\
2nd DEAE-Sephadex & APP-I & 26.7 & 0.027 & 22 & 5.3 \\
& APP-II & 14.8 & 0.14 & 25 & 20.8 \\
DEAE-5PW (HPLC) & APP-I & 2.61 & 0.08 & 14 & 16.1 \\
Phenyl-5PW (HPLC) & APP-I & 1.02 & 0.14 & 2.4 & 27 \\
& & & 0.21 & 1 & 41 \\
\hline
\end{tabular}

\section{Effects of chemicals}

Both enzymes were activated $3 \sim 4$ fold by the addition of $5 \mu \mathrm{M} \mathrm{Mn}^{2+}$ (Fig. 6), and were inhibited by EDTA. The enzymes inactivated with EDTA were reactivated by adding $\mathrm{Mn}^{2+}$. Both enzymes were partially inhibited by PCMB but were not affected by DFP, iodoacetic acid, bacitracin, bestatin, leupeptin, pepstatin, puromycin, or E-64.

\section{Substrate specificity}

Both enzymes released the amino terminal amino acid from peptides when proline was in the penultimate position. The velocity of peptide hydrolysis by the enzymes was not significantly different for most $\mathrm{X}$-Pro bonds $(\mathrm{X}=$ amino acid) or peptides, except for Pro-Pro bonds. APP-II hydrolyzed (Pro-Pro-Gly) much faster than APP-I.

\section{DISCUSSION}

The classical assay method by ninhydrin reaction with poly-proline had some problems: the precise assay of the enzyme activity is impossible, since crude preparations contain 


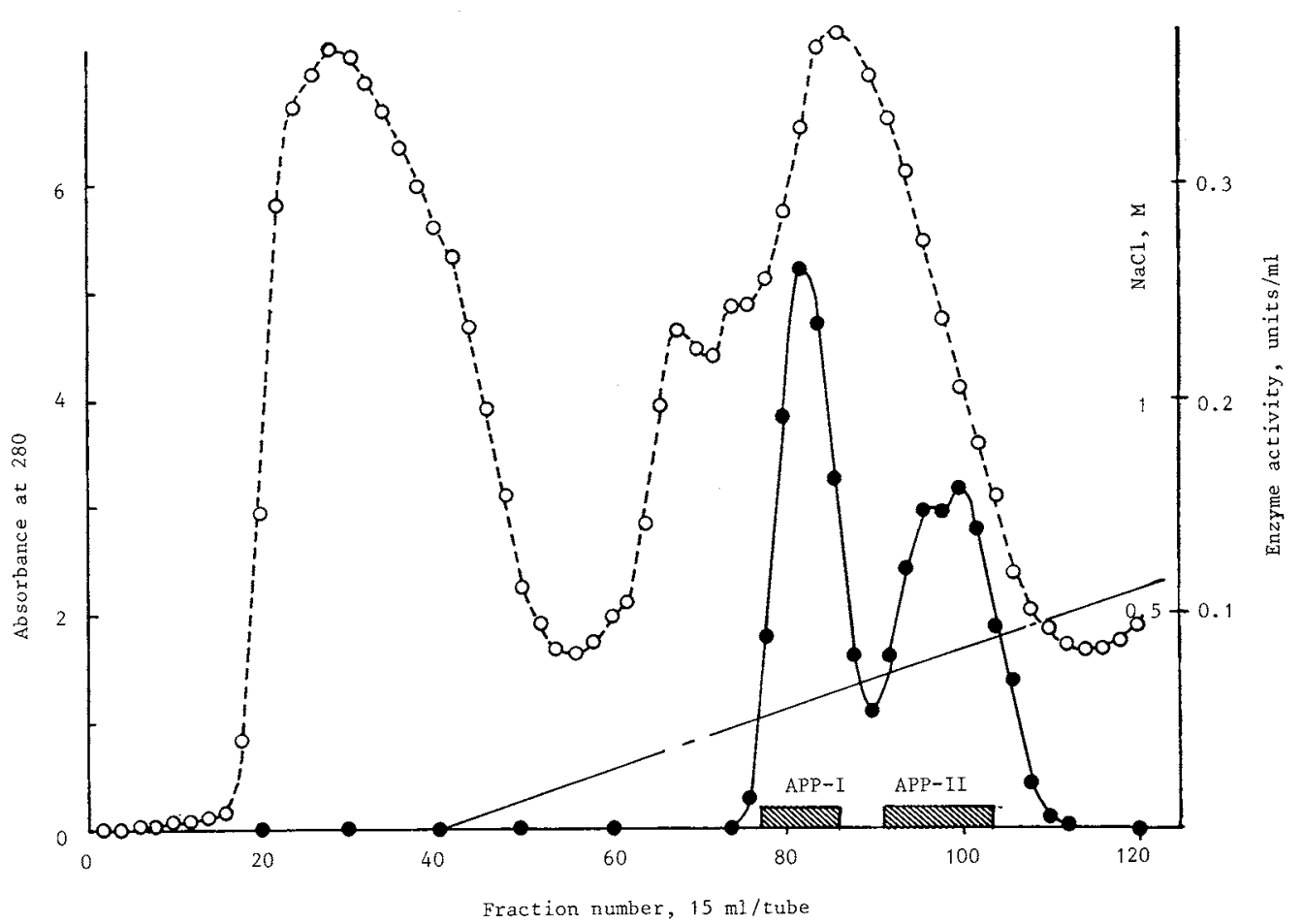

Fig. 4. Chromatogram of Crude Enzyme Preparation of Aminopeptidase P from E. coli HB101 on DEAESephadex.

The column $(2.5 \times 30 \mathrm{~cm})$ equilibrated with $20 \mathrm{~mm}$ borate- $\mathrm{Na}$ buffer, $\mathrm{pH} 9.0$, was used and the adsorbed enzyme was eluted with an increasing linear gradient of $\mathrm{NaCl}$ concentration to $0.4 \mathrm{M}$. $\mathrm{O}--\mathrm{O}$, absorbance at $280 \mathrm{~nm}$; - - , enzyme activity.

Table II. Some Enzymatic and Physicochemical Properties of Two TyPes of AMINoPEPTIDASE P FROM $E$. coli HB101

\begin{tabular}{lcc}
\hline & APP-I & APP-II \\
\hline Optimum pH & 8.0 & 9.0 \\
pH stability & 10 & $8 \sim 9$ \\
Optimum temperature $^{b}$ & $55^{\circ} \mathrm{C}$ & $41^{\circ} \mathrm{C}$ \\
Thermal stability $^{c}$ & $60^{\circ} \mathrm{C}$ & $50^{\circ} \mathrm{C}$ \\
Molecular weight & 350,000 & 210,000 \\
\hline
\end{tabular}

a $70 \%$ remaining activity after incubation at $37^{\circ} \mathrm{C}$ for $30 \mathrm{~min}$.

b At $\mathrm{pH} 8.0$.

c For $50 \%$ remaining activity after incubation for $30 \mathrm{~min}$ at $\mathrm{pH} 8$.

large amounts of ninhydrin-positive substances and since the substrate is hydrolyzed by an intracellular proline iminopeptidase found in E. coli. On the contrary, our assay method using Gly-Pro-chromogen coupled with proline iminopeptidase can be used not only for a routine assay but also screening for the enzyme activity in crude enzyme preparations. While Gly-Pro-chromogen is also a substrate for dipeptidyl aminopeptidase IV, this activity has not been detected in $E$. coli. These three procedures with three different substrates have some merits. $\beta$-Naphthylamine liberated from $\beta$-naphthylamide substrate shows a bright red color by coupling with Fast Garnet GBC. Thus, it is very easy to detect the enzyme activity in the crude preparation. The $p$ nitroanilide substrate can be monitored after enzymatic hydrolysis in their reaction tubes. The digestion product, 4-methyl-7-aminocoumarin, from the coumarin substrate is a highly sensitive fluorogenic compound. When this assay method is applied to the other sources which are contaminated with dipeptidyl aminopeptidase IV, it is possible to avoid the 


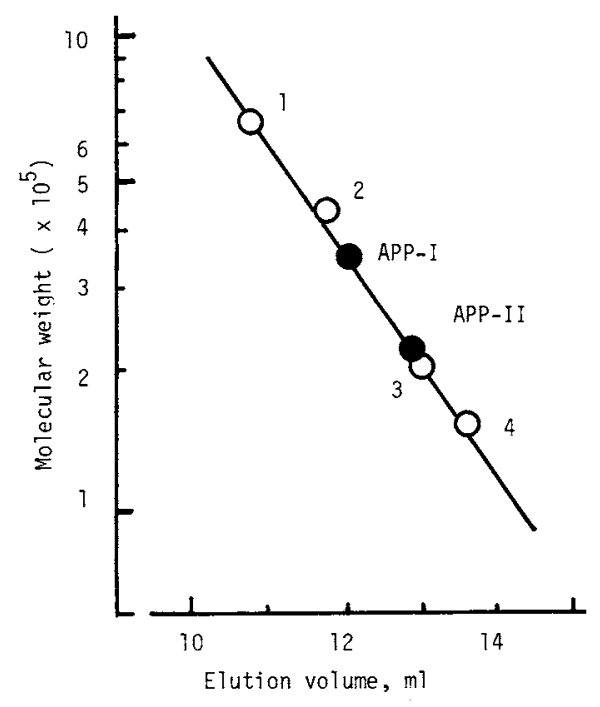

FrG. 5. Estimation of the Molecular Weight of the Enzyme by Gel Filtration on HPLC Using a TSK 3000SW Column.

1, thyroglobulin (MW 669,000); 2, apoferritin (MW 443,000 ); 3, $\beta$-amylase (MW 200,000); 4, alcohol dehydrogenase (MW 150,000). Flow rate, $0.7 \mathrm{ml} / \mathrm{min}$; pressure, $30 \mathrm{~kg} / \mathrm{cm}$; temperature, $25^{\circ} \mathrm{C}$; solvent, $20 \mathrm{~mm}$ Tris $-\mathrm{HCl}$ buffer, $\mathrm{pH} 7.5$ containing $0.1 \mathrm{M} \mathrm{NaCl}$; detector, UV monitor at $280 \mathrm{~nm}$.

\section{Table III. EFFects of Several Inhibitors} ON ENZYME FROM $E$. coli HB101

The reaction mixture consisting of 0.1 unit of enzyme, chemicals, or metal salts, in $100 \mu \mathrm{l}$ of $50 \mathrm{~mm}$ borate- $\mathrm{Na}$ buffer, pH 9.0 , was incubated at $37^{\circ} \mathrm{C}$. After $20 \mathrm{~min}$, the remaining activities were assayed by the standard method using Gly-Pro-2-NNap.

\begin{tabular}{lccc}
\hline \multirow{2}{*}{ Inhibitors } & & \multicolumn{2}{c}{ Remaining activity } \\
\cline { 3 - 4 } & & APP-I & APP-II \\
\cline { 3 - 4 } Control & & 100 & 100 \\
EDTA & 1 & 2 & 1 \\
o-Phenanthroline & 1 & 118 & 49 \\
DFP & 1 & 97 & 107 \\
PCMB & 0.06 & $35^{*}$ & $30^{*}$ \\
Iodoacetic acid & 1 & 92 & 86 \\
Bacitracin & 1 & 112 & 84 \\
Bestatin & 1 & 106 & 95 \\
Leupeptin & 1 & 87 & 74 \\
Pepstatin & 1 & 103 & 60 \\
Puromycin & 1 & 140 & 91 \\
E-64 & 1 & 109 & 102 \\
\hline
\end{tabular}

* Remaining activity was assayed by the ninhydrin method using (Pro-Pro-Gly) $)_{5}$ as substrate.

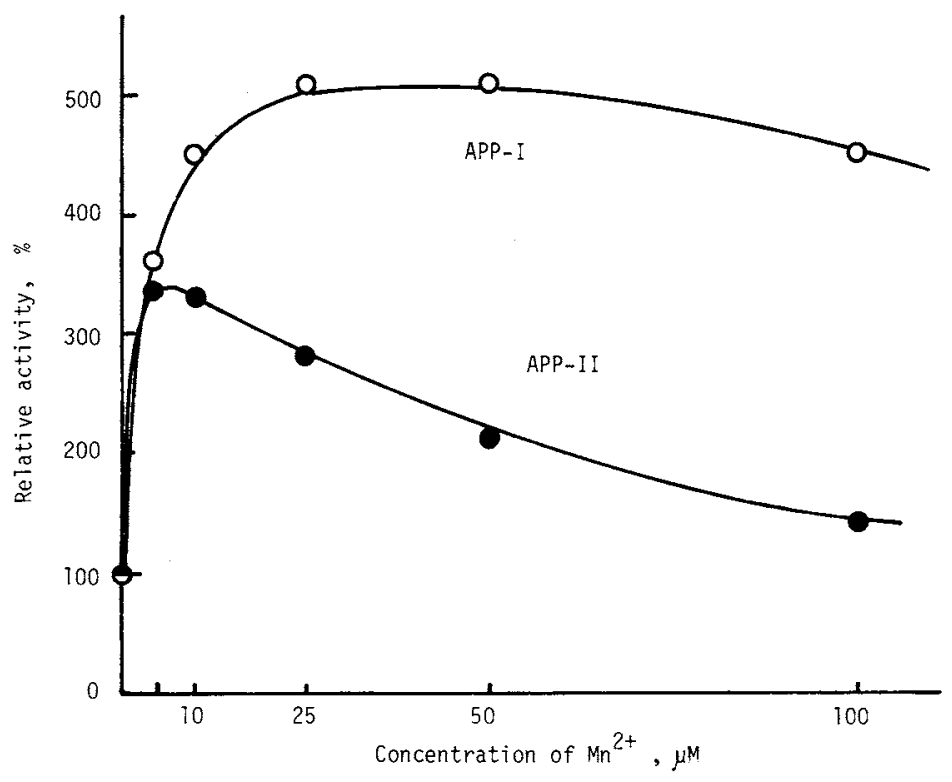

FIG. 6. Effects of Mn on Enzyme Activity of Aminopeptidase P.

After the enzyme was incubated with various concentration of $\mathrm{Mn}^{2+}$ at $\mathrm{pH} 7.5$ for $5 \mathrm{~min}$, activities were assayed by standard assay method using Gly-Pro-2-NNap as substrate. 
Table IV. Substrate Specificity of Aminopeptidase P FROM E. coli $\mathrm{HB} 101$

\begin{tabular}{|c|c|c|}
\hline \multirow{2}{*}{ Substrates } & \multicolumn{2}{|c|}{ Relative rate of hydrolysis } \\
\hline & APP-I & APP-II \\
\hline Gly $\downarrow_{\text {Pro-2-NNap }}$ & 100 & 100 \\
\hline 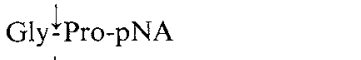 & 170 & 241 \\
\hline Ala $₫$ Pro-pNA & 443 & 1131 \\
\hline Glu£ Pro-pNA & 113 & 541 \\
\hline His $£$ Pro-pNA & 149 & 453 \\
\hline Lys-Pro-pNA & 415 & 986 \\
\hline 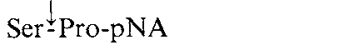 & 150 & 466 \\
\hline Pro-Pro-Gly-(Pro-Pro-Gly) ${ }_{4}$ & 18 & 354 \\
\hline 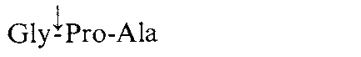 & + & + \\
\hline Gly $\unrhd$ Pro-Phe & + & + \\
\hline Gly $\downarrow$ Pro-Leu-Gly & + & + \\
\hline
\end{tabular}

The following compounds were not hydrolyzed: Z-GlyPro-2-NNap, Z-Pro-2-NNap, Pro-2-NNap, Gly-Ala, LeuPhe.

enzymatic hydrolysis by adding DEP.

Contrary to Yaron and Mlynar ${ }^{1)}$ who reported only one enzyme in $E$. coli, we could find two types of the enzymes in $E$. coli HB101. It remains unclear whether this discrepancy is due to the differences in the strains used, purification methods, or enzyme assay methods, but it seems likely that Yaron and Mlyner failed to detect APP-I, since they used poly-proline, which will be a poor substrate for APP-I as seen with oligo Pro-Pro-Gly (Table IV).
Except for Pro-Pro bond hydrolysis by APP-I, the rates of peptide hydrolysis by both enzymes were not significantly different by the kind of amino acids at the Pl site of substrate. Moreover, the enzymes are thermally stable, and higher optimum $\mathrm{pH}$ and stability at higher pHs will help for removal of an amino terminal amino acid under denaturating conditions in alkaline conditions, indicating that the enzymes are good tools for processing amino terminals of peptides.

To study the details of enzymatic characteristics and protein structure, we attempted the cloning of the enzymes and succeeded in the expression of APP-II, ${ }^{10)}$ and are now studying the nucleotide sequencing.

\section{REFERENCES}

1) A. Yaron and D. Mlynar, Biochem. Biophys. Res. Commun., 32, 658 (1968).

2) K. C. S. Chen and T. M. Buchanan, J. Biol. Chem., 255, 1704 (1980)

3) P. Dehm and A. Nordwig, Eur. J. Biochem., 17, 364 (1970).

4) J. Lasch, R. Koelsch, A.-M. Ladhoff and B. Hartrodt, Biomed. Biochim. Acta, 45, 833 (1986).

5) T. Yoshimoto, Y. Tamesa, K. Gushi, N. Murayama and D. Tsuru, Agric. Biol. Chem., 52, 217 (1988).

6) T. Yoshimoto and D. Tsuru, J. Biochem., 97, 1477 (1985).

7) T. Yoshimoto, T. Kita, M. Ichinose and D. Tsuru, $J$. Biochem., 92, 275 (1982).

8) T. Yoshimoto, R. Walter and D. Tsuru, J. Biol. Chem., 255, 4786 (1980).

9) G. Bernardi, Methods Enzymol., 22, 325 (1971).

10) T. Yoshimoto, N. Murayama, T. Honda, M. Tone and D. Tsuru, J. Biochem., 104, 93 (1988). 